DOI https://doi.org/10.32837/app.v0i65.312

УДК 324:659.4] (091) (045)

\title{
ТРАНСФОРМАЦІЯ ВИБОРЧИХ ТЕХНОЛОГІЙ У ПРОЦЕСІ ФОРМУВАННЯ ІНФОРМАЦІЙНОГО СУСПІЛЬСТВА
}

Виборчі компанії перетворилися на важливу складову частину політичного життя сучасного українського суспільства, а виборчі технології відіграють потужну роль у формуванні політичних процесів та інститутів в політичний сфері суспільства. На практиці стає зрозуміло, що в сучасних умовах суспільно-політичного життя України боротьба за виборчі посади стає все інтенсивнішою через застосування виборчих технологій, які дедалі більше використовуються в кожній виборчій кампанії, будуються на основі інформаційного ресурсу та забезпечують кандидатам шанси на перемогу. За допомогою сучасних виборчих технологій політики-кандидати розширюють свої можливості в комунікації з виборцем і здійснюють формування конкретних кроків у досягненні політичних цілей.

У сучасних умовах інформаційні виборчі технології все більше використовуються для боротьби за владу. Усе більшого поширення в політичному процесі набувають інтернет-блоги, соціальні мережі, форуми, що використовуються для агітації та залучення прихильників, донесення політичних програм, організації та координації масових акцій.

Інформаційна мережа формує середовище, яке має широкі можливості для комунікації, тому використання інформаційних технологій у виборчому процесі веде до покращення взаємодії серед учасників політичного процесу.

Інформаційна революція, яка відбулася у світі наприкінці XX - на початку XXI ст., привела до того, що інформація стала відігравати ключову роль у світовому соціально-економічному процесі. Можливості широкого впровадження й удосконалення техніко-технологічних засобів, які задіяні у збиранні, зберіганні, використанні та поширенні інформації, стали передумовою стрімкого поширення інформаційних відносин у суспільстві.

Інформаційні технології починають використовуватися в усіх сферах суспільного життя, що несе за собою відкритість суспільств та декларує поширення демократії. Ураховуючи те, що з початком формування інформаційного суспільства інформаційні технології стали ефективним інструментом управління свідомістю мас, їх застосування в політичних процесах, зокрема й у вигляді виборчих технологій, набуває першочергового значення під час виборчих перегонів (виборів).

Аналіз останніх досліджень і публікацій. Дослідженням у сфері інформаційного суспільства приділена увага як західних, так і вітчизняних учених. Серед них можемо виділити прізвища В. Бебика, Д. Белла, П. Друкера, М. Кастельса, И. Масуди, Ф. Махлупа, Л. Мельника, I. Сопілко, А. Тоффлера. Сутність виборчих технологій, їхнє місце у структурі вітчизняних соціально-політичних відносин та вплив на виборчі процеси вивчають низка українських науковців: І. Поліщук, А. Романюк, Г. Почепщов, О. Валевський та ін. Але водночас питання функціонування виборчих технологій в умовах формування інформаційного суспільства вивчені недостатньо.

Метою статті є дослідження трансформації виборчих технологій в умовах формування інформаційного суспільства.

Виклад основного матеріалу. Активне вивчення перспектив розвитку інформаційного суспільства почалося із другої половини XX ст. Ф. Махлуп у роботі «Виробництво і розподіл знань у США» (Machlup, 1962) показав, що вже в 1960-70-х рр. виробництво і розподіл інформації стали провідною галуззю національного господарства розвинутих країн світу.

Одна 3 найвідоміших теорій інформаційного суспільства належить Е Тоффлеру, який у своїй книзі «Третя хвиля» (Тоффлер, 1999) виділив у процесі суспільної еволюції три етапи, 
які він назвав «хвилями». Так, перша хвиля була названа аграрним суспільством, оскільки основна економічна діяльність була пов' язана з виробництвом продуктів харчування. На зміну їй прийшла «друга хвиля» у вигляді індустріального суспільства, яке характеризувалося виробництвом промислових товарів. Із середини XX ст. починає зароджуватися і набирати сили «третя хвиля», яка проголосила початок новому суспільству, інформаційному, де головними продуктами виробництва стали інформація та знання.

Важливою складовою частиною інформаційного суспільства Е. Тоффлер уважає диверсифікацію інформаційних каналів. Зростає кількість засобів масової інформації, а їхній зміст стає більш різноманітним і спрямованим на певну аудиторію. Сучасні інформаційно-комунікаційні технології дозволяють користувачеві обирати потрібний канал інформації, зокрема інтернет-засоби: інтернет-телебачення, інтернет-радіо, соціальні мережі, різноманітні розважальні й інформаційні сайти тощо. Цими засобами користуються політтехнологи, які розробляють і впроваджують різні технології у виборчий процес.

Усе частіше використовуються блоги, соціальні мережі, різноманітні форми для агітації, донесення політичних програм, а також координації масових акцій.

Це говорить про те, що технологічні зміни не залишили поза увагою і виборчий процес. Виборчі технології через сукупність засобів і алгоритмів цілеспрямованого політико-технологічного впливу на електоральні настрої та поведінку, а також на результати голосування для досягнення цілей у виборчій кампанії вже стали невід' ємною складовою частиною вітчизняних електоральних процесів (Величко, 2014).

Будучи відносно новим поняттям у політичній науці, виборчі технології пов'язуються з організацією та проведенням демократичних виборів. Виборчі технології покликані забезпечити найважливішу сферу взаємодії держави і громадянського суспільства за допомогою процедури виборів, а саме передання владних повноважень представникам суспільства (Поліщук, Моторнюк, 2011, с. 191).

Важливою частиною виборчого процесу в інформаційному суспільстві $є$ технологізація методів підготовки, організації та проведення перевиборчих кампаній.

Проведення вибрів у суспільстві говорить про його демократичність, спроможність мирними політичними механізмами вирішувати важливі проблеми. Вибори є одним із механізмів легітимізації вади, що забезпечують політичну стабілізацію в суспільстві (Свекла, 2015, с. 220).

У більш розгорнутому вигляді виборчі технології становлять частину політичних технологій, хоча водночас чітке розмежування політичних і виборчих технологій можна провести лише формально. Виборчі технології застосовуються на старті виборчих перегонів, строки проведення яких закріплені законодавчо. Завершується процес застосування виборчих технологій разом із формальним закінченням виборчих перегонів, незважаючи на те, що часто-густо терміни застосування виборчих технологій довші, ніж тривалість офіційної виборчої компанії (Виборчі технології, 2010).

За інформаційного суспільства все більшого значення набуває інноваційність виборчих технологій. Сучасні комп'ютери та спеціальні комп'ютерні системи можуть використовуватися політичними силами для збору й обробки необхідних даних.

Політична наука виділяє кілька етапів в історії розвитку виборчих технологій.

Перший етап - так-звана «газетна епоха». У цей період політична комунікація здійснювалася здебільшого через агітаторів, плакати, партійну пресу. В основному агітаційною кампанією займалися члени партії і добровольці. Для підтримки певного кандидата мобілізовувався місцевий електорат і організовувалися агітаційні поїздки політиків виборчим округом.

Оскільки цільову аудиторію становили переважно соціальні категорії населення, то акцент робився не стільки на агітацію, скільки на мобілізацію населення. Основою комунікаційної стратегії передвиборчої кампанії була пропаганда.

Другий етап у розвитку виборчих технологій дістав умовну назву «телевізійна епоха», оскільки він був тісно пов'язаний із розвитком засобів масової комунікації і професіоналізацією PR-компаній. Саме в цей час почали з' являтися спеціалісти, які займалися детальною підготовкою до виборів. Акцент робився на основному засобі комунікації тих часів - телебаченні. Головна увага фокусувалася на політиках-кандидатах, а виборчий штаб працював над 
виробленням однакових меседжів для всіх регіонів країни, кандидати намагалися отримати підтримку всіх соціальних груп.

Третій етап у розвитку виборчих технологій дістав назву «цифрова епоха». Він почався зі створення та впровадження в широке використання нових телекомунікаційних технологій (кабельне та супутникове телебачення, інтернет). Саме ці інформаційні технології дали змогу зорієнтувати виборчі кампанії на виборця-споживача, підлаштовуватися під його інтереси та проблеми. Із приходом «цифрової ери» у виборчі технології партійна конкуренція починає все більше пристосовуватися до уподобань виборців, а не змінювати їхні уявлення (Ільницький, 2018).

Сучасні виборчі технології можуть типологізуватися за різними характеристиками: сферою застосування, рівнем інноваційності, витратами, які пов'язані з їх застосуванням, ступенем лояльності тощо. Усе більшого значення у процесі формування інформаційного суспільства набуває інформативність виборчих технологій, які використовують сучасний інформаційний потенціал і все більше беруть участь у передвиборчому процесі.

Володіння засобами масової комунікації розширює можливості представників політичних сил. Вони можуть не лише висвітлювати позитивну інформацію про себе та свою політичну силу, але й поширювати інформацію про своїх конкурентів, яка має компрометуючий характер.

Додавання інформаційної складової частини у виборчі технології змінило їі функціональність. Інформаційні технології стали потужною складовою частиною виборчих засобів.

Сфера застосування політичних технологій постійно збілышується. Комп'ютери та мережа Інтернет можуть використовуватися політичними силами для збору й обробки персональних даних. Сучасні інформаційні технології дозволяють запровадити принцип діалогового зв'язку. За допомогою цих можливостей політики можуть розширювати свою участь у політико-інформаційному обміні. Також інформаційні технології надали можливість пересічним користувачам Інтернету виражати свої думки та погляди стосовно важливих політичних питань, які миттєво можуть поширюватися в суспільстві, що веде до плюралізму і гласності.

Ефективні дії в цьому напрямі (належне опрацювання та використання інформації, яку отримано від виборців) дозволяють політтехнологу організувати індивідуальну роботу з кожним виборцем. Отже, коли політик виступає перед аудиторією, він адресує свій виступ конкретним громадянам, може порушувати ті проблеми, які їх хвилюють. Це показує громадянам рівень компетентності політика, що веде до зростання рейтингу останнього на певній території.

Такий підхід у демонстрації компетенції у проблемних питаннях і пропонування шляхів ïx вирішення є важливим механізмом залучення потенційних виборців на свій бік, якщо вони ще не визначилися зі своїм вибором. Пропонування виборцю кращого варіанта розв'язання проблем, що його турбують, може загітувати тих виборців, які були першочергово налаштовані на підтримку іншого кандидата.

Підвищення рівня можливостей використання виборчих технологій із високим вмістом інформаційної компоненти дозволило перевести на новий рівень відносини між політикамикандидатами та потенційними виборцями, а саме перевести ці відносини у форму партнерських стосунків (Поліщук, 2015).

Розвиток інформаційних технологій спричинив удосконалення медіаринку, що привело до розширення можливостей формування влади і тиску на електорат. Це забезпечує бажаний результат на виборах.

Використання сучасних засобів комунікації у виборчому процесі посприяло тому, що політикою почала цікавитися все більша кількість людей молодшого віку. Центром прикладних досліджень було проведено соціологічні дослідження у 2018 р., які показали, що 73\% українців старше 18 років активно цікавляться політикою. Поруч із пенсіонерами та громадянами, старшими за 55 років, найбільш активною електоральною групою є люди віком 35-44 роки. Саме у 2018 р. Інтернет як спосіб отримання політичної інформації наздогнав та випередив за рейтингом телебачення. Приблизно 70\% виборців отримують інформацію $з$ телевізора та через мережу Інтернет. Часто така інформація надходить комбіновано.

Таке джерело отримання новин, як Facebook, витіснило традиційні засоби масової інформації (далі - 3MI). Так, за допомогою Facebook інформацію отримують майже 49\% виборців, тоді як із традиційних 3MI - 43,5\%. Це говорить про зниження зацікавленості населення у традиційних 
3MI, зміну пріоритетів в отриманні інформації, зростання недовіри до традиційних ЗМІ та підвищення ролі неформальної комунікації, що, як було описано вище, веде до партнерських стосунків між політиками-кандидатами і потенщійними виборцями. Це досить сильно проявляється у віковому розрізі до 35 років, оскільки саме в цієї групи осіб Інтернет посідає перше місце як канал отримання новин про політику. Водночас лідерство утримують соціальні мережі.

Особи віком 35-44 роки використовують Інтернет на рівні з телевізором, а вже в осіб віком старше 45 років рівень використання Інтернету як джерела інформації знижується, а основним каналом отримання інформації виступає телебачення. У вікової категорії 65 років і старше з телевізором конкурує ще друкована преса (Новые рейтинги, 2018).

Початок широкого використання виборчих технологій в Україні припав на час здобуття незалежності та скасування монополії на державну владу компартії, що, у свою чергу, стало початком проведення конкурентних виборів на багатопартійній основі з використанням останніх інформаційних досягнень та різноманітних виборчих технологій.

Висновки. Підсумовуючи вищенаведене, можемо зазначити, що розвиток виборчих технологій завжди відбувається відповідно до вимог часу, оскільки вони є надзвичайно динамічними та постійно вдосконалюються. Інформаційне суспільство перетворило виборчі технології на частину інформаційно-комунікаційної системи. Це відбулося через розширення можливостей 3МІ та механізму донесення необхідної інформації до потенційних виборців.

У сучасних реаліях боротьба за владу проявляється не стільки в конкуренції програм політичних партій чи кандидатів, скільки в боротьбі віртуальних образів за допомогою засобів масової інформації. Останні виборчі перегони свідчать про надзвичайну ефективність інформаційних технологій під час виборчого процесу.

Щоб отримати перевагу під час виборів, політичні сили повинні бути компетентними в останніх досягненнях науково-технічного прогресу, зокрема й у сфері інформаційних можливостей, бути готовими застосовувати їх на практиці.

Дослідження виборчих технологій та інформаційних можливостей є важливим напрямом сучасної політичної науки, оскільки вони суттєво впливають на розвиток процесів державотворення. Підвищення рівня використання інформаційних технологій у всіх сферах суспільного життя веде до ефективності та прозорості політичної влади та державного управління.

\section{Лimepamypa:}

Величко Т. Виборчі технології та їх вплив на політичну свідомість сучасної молоді. Наука $і$ життя: сучасні тенденції. 29-31 травня 2014 р. URL: https:/ /int-konf.org/en/2014/nauka-i-zhittya-suchasni-tendentsiji-2931-05-2014/803-velichko-t-a-viborchi-tekhnologiji-ta-jikh-vpliv-na-politichnu-svidomist-suchasnoji-molodi.

Виборчі технології: сутність та різновиди. Навчальні матеріали онлайн. URL: https://pidruchniki.com/ 1339061355285/politologiya/viborchi_tehnologiyi_sutnist_riznovidi.

Ільницький М. Виборчі технологи як форма правореалізації. Национальный юридический журнал: теория и практика. Молдова, 2018. № 1(3). С. 21-24.

Новые рейтинги: Тимошенко отрывается от Порошенко, Зеленский выходит на 3-е место. Центр прикладных исследований. URL: https://cpd.com.ua/ru/reitingi-kandidatov-v-prezidenty.

Поліщук І. Виборчі технології: сутність та різновиди. Вісник Національного університету «Юридична академія України імені Ярослава Мудрого». Серія «Філософія, філософія права, політологія, соціологія». 2015. № 4. C. 106-112.

Поліщук І., Моторнюк Т. Поняття «виборчі технології»: основні концептуальні підходи. Вісник Національної юридичної академії України імені Ярослава Мудрого. Політологія. 2011. № 7. С. 189-200.

Свекла К. Функціональні особливості виборчих технологій та їх вплив на масову свідомість. Актуальні проблеми політики. 2015. № 56. С. 219-227.

Тоффлер Е. Третя хвиля. Київ : Видавничий дім «Всесвіт», 2000. 480 с.

Machlup F. The Production and distribution of Knowledge in the United States. Princeton, NJ : Princeton University Press, 1962.

\section{References}

Velychko T.A. (2014), Vyborchi tekhnolohii ta yikh vpyv na politychnu svidomist suchasnoi molodi [Electoral technologies and their impact on the political consciousness of modern youth]. URL: https://int-konf.org/ en/2014/nauka-i-zhittya-suchasni-tendentsiji-29-31-05-2014/803-velichko-t-a-viborchi-tekhnologiji-ta-jikhvpliv-na-politichnu-svidomist-suchasnoji-molodi. [in Ukrainian] 
Vyborchi tekhnolohii: sutnist ta riznovydy. Navchalni materialy onlain. [Electoral technologies: essence and varieties. Online learning materials.]. URL: https:// pidruchniki.com/1339061355285/politologiya/viborchi_ tehnologiyi_sutnis_riznovidi. [in Ukrainian]

Ilnytskyi M. (2018), Vyborchi tekhnolohy yak forma pravorealizatsii [Electoral technologists as a form of law enforcement], journal Natsyonalnyi yurydycheskyi zhurnal: teoryia y praktyka [National Legal Journal: Theory and Practice], vol.1(3), pp. 21-24. [in Ukrainian]

Novie reitynhy: Tymoshenko otrivaetsia ot Poroshenko, Zelenskyi vikhodyt na 3-e mesto. [New ratings: Tymoshenko breaks away from Poroshenko, Zelensky comes in 3rd place]. Tsentr prykladnykh yssledovanyi. [Centre for Applied Research]. URL: https://cpd.com.ua/ru/reitingi-kandidatov-v-prezidenty. [in Russian] Polishchuk I.O. (2015), Vyborchi tekhnolohii: sutnist ta riznovydy [Electoral technologies: essence and varieties], Visnyk Natsionalnoho universytetu "Iurydychna akademiia Ukrainy imeni Yaroslava Mudroho". Seriia: Filosofiia, filosofiia prava, politolohiia, sotsiolohiia [Bulletin of the National University "Yaroslav Mudryi Law Academy of Ukraine". Series: Philosophy, philosophy of law, political science, sociology], vol. 4, pp. 106-112. [in Ukrainian]

Polishchuk I.O., Motorniuk T.M. (2011), Poniattia "vyborchi tekhnolohii": osnovni kontseptualni pidkhody [The concept of "electoral technology": basic conceptual approaches], Visnyk Natsionalnoho universytetu "Iurydychna akademiia Ukrainy imeni Yaroslava Mudroho". Seriia: Politolohiia [Bulletin of the National University "Yaroslav Mudryi Law Academy of Ukraine". Series: Politology], vol, 7, pp. 189-200. [in Ukrainian]

Svekla K.A. (2015), Funktsionalni osoblyvosti vyborchykh tekhnolohii ta yikh vplyv na masovu svidomist [Functional features of electoral technologies and their influence on the mass consciousness], Aktualni problemy polityky [Current policy issues], vol. 56. pp. 219-227. [in Ukrainian]

Toffler A. (2000), Tretia khvylia [The Third Wave], Press Vydavnychyi dim Vsesvit, Kyiv, 156 p. [in Ukrainian] Machlup F. (1962), The Production and distribution of Knowledge in the United States. Princeton, NJ: Princeton University Press. [in English]

\section{Анотація \\ Чубатенко О. М. Трансформація виборчих технологій у процесі формування інформаційного суспільства. - Стаття.}

У статті розглянуто етапи еволюції суспільства від аграрного до інформаційного. Зазначено, що важливою характеристикою інформаційного суспільства є збільшення кількості засобів масової комунікації, які дозволяють користувачеві обирати потрібний канал інформації, зокрема інтернет-сайти, інтернет-телебачення, інтернет-радіо, соціальні мережі тощо. Ці засоби використовують політтехнологи, які розробляють і впроваджують різні технології у виборчий процес. У статті говориться про те, що виборчі технології становлять невід'ємну складову частину політичного життя сучасного суспільства, вони відіграють значну роль у формуванні політичних процесів та інститутів у політичній системі, а виборчі кампанії посіли місце важливої складової частини політичного життя українського суспільства. Проаналізовано сучасні виборчі кампанії, які показують, що в сучасних аспектах суспільного життя України передвиборча боротьба стає все інтенсивнішою, оскільки все більше передвиборчих кампаній будуються на застосуванні виборчих технологій із використанням інформаційних ресурсів, що підвищує шанси кандидата на перемогу. Сучасні інформаційні технології дозволяють політикам-кандидатам регулювати свої можливості під час комунікації з виборцем та вимагають здійснити конкретні кроки в досягненні політичної мети. У статті розкривається еволюція виборчих технологій, які пройшли газетний, телевізійний та цифровий шляхи розвитку. Додавання інформаційної складової частини у виборчі технології дозволило їм перетворитися на потужну частину виборчих засобів, які все більше використовують інформаційні технології в боротьбі за владу. Зазначено, що в сучасних реаліях боротьба за владу ведеться не стільки через конкуренцію політичних партій та передвиборчих програм, скільки через боротьбу віртуальних образів, які створюються інформаційними технологіями, що застосовуються у виборчому процесі. Останні виборчі перегони в Україні й інших державах доводять ефективність застосування інформаційної складової частини під час виборів. У висновках наголошено на важливості дослідження виборчих технологій та інформаційних можливостей у сучасній політичній науці, оскільки вони як складник виборчих процесів істотно впливають на розвиток процесів державотворення.

Ключові слова: інформаційне суспільство, інформаційні технології, виборчі технології, вибори, виборча кампанія.

\section{Summary}

Chubatenko O. M. Transforming electoral technologies in the process of shaping information society. Article.

The article considers the stages of society evolving from to the agrarian to the information. It is noted that an important characteristic of the information society is the increase in the number of media allowing the user 
to choose the desired information channel, including websites, online television, online radio, social networks and so on. These tools are used by political technologists who develop and implement various technologies in the electoral process. The article states that election technologies that constitute an integral part of the political life of the modern society, they play a significant role in shaping political processes and institutions in the political system, while election campaigns have taken up the place of an important component of Ukrainian society. Modern election campaigns are analyzed, showing that among modern aspects of Ukrainian social life, the election campaign is becoming more intense, as more and more election campaigns are based on using election technologies using information resources, which increases the candidate's chances for victory. Modern information technologies allow candidate politicians to adjust their capabilities in communicating with the voter and require taking particular steps in achieving their political goal. The article reveals the evolution of election technologies that have gone through newspaper, television and digital development path. Adding the information component to election technologies has allowed them to become a powerful part of the election media, which are increasingly using information technology in the struggle for power. It is noted that in modern realities the struggle for power is led not so much through the competition of political parties and election programs, but through the fight of virtual images created by information technology used in the election process. The recent election campaigns in Ukraine and other countries have proven the effectiveness of the information component during elections. The conclusions emphasize the importance of studying election technologies and information opportunities in modern political science, because as a part of electoral processes, they have a great influence on developing state-building processes.

Key words: information society, information technology, election technologies, elections, election campaign. 